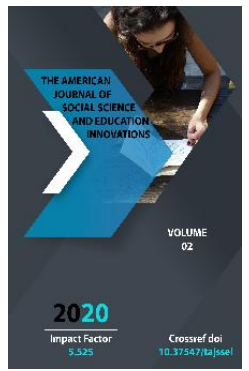

Journal Website: http://usajournalshub.c om/index,php/tajssei

Copyright: Original content from this work may be used under the terms of the creative commons attributes 4.0 licence.

\section{Microtoponymy Of Cities Of Bukhara Khanate And Their Classification (Based On The Analysis Of Travelogues Of Russian Tourists Of The XVIII-XIX Centuries)}

\author{
Bekhzodjon Ilkhomjon Ugli Zokirov \\ Lecturer, History And Ethnology Of The People Of Central Asia" Tashkent State University of \\ Oriental Studies, Uzbekistan
}

\title{
ABSTRACT
}

In this article, it is analyzed dissociatedly that toponyms which are mentioned in the travelogue of Russian tourists who visited the Bukhara Emirates. The main reason why it is studied specifically is that their frequent transformation can provide a wealth of scientific information about the socioeconomic, political, and cultural life of the study area in a limited period. Additionally, the article gives information about socio-economic and cultural-spiritual features of cities which existed in the emirate of Bukhara in the 18-19th centuries.

\section{KEYWORDS}

Russian travelers, microtoponymy, gateways, mosque, madrassah, graveyard, Chorsu, Registan, Mausoleum.

\section{INTRODUCTION}

In the memories written by Russian travelers, merchants, and also ambassadors while their journey not only toponyms are mentioned but also the name of some objects. This point of view, this article has been written to analyze separately microtoponym which is referred to in Russian travelers' travelogue. First of all, we need to explain the concept of urban microcolony, which is used in the context of toponymy, which is a vast area. The city 
microtoponym implies city gateways, mosque, madrassah, graveyard, bazaar, hostels, pond, bath-house, and others.

\section{THE MAIN RESULTS AND FINDINGS}

\section{City gates of the Bukhara Khanate}

We know that during the Khanate period, the main cities were surrounded by defensive walls, through which the exit and entrance to the city were carried out directly through the city gates. Therefore, during these periods, great importance was attached to the security and strategic location of the city gates, as well as their convenience for the outskirts. In particular, many information about the gates of Bukhara can be found in the works of Russian tourists. In particular, Fyodor Skibin, who visited Khiva in 1697, noted that Bukhara had "twelve gates to enter it" [3; 76-80]. The number of city gates in the relics of F.Beneveni [5; 120], who visited the Bukhara Khanate in the subsequent period remains unchanged. In the diaries of F.S.Efremov, who visited the khanate at the end of the 18th century, it was noted that there were 11 gates in the city of Bukhara $[6 ; 95]$. It is clear that by the second half of this century, the number of 12 gates at the beginning of the 18th century had decreased to one. I.V.Vitkevich, who arrived in Bukhara with P.I.Demezon, left the following comment in his diaries: “... they say that there are 12 gates in Bukhara; when I forced the inhabitants of Bukhara to call the city gate by name, it was not always the only gate. Later I heard that one of the gates (with the ground) was closed". [2;98]. If we look at the analysis of the above considerations, then the fact that the twelfth gate of Bukhara remained underground dates back to the middle of the 18th century. However, the travel notes of the above authors do not mention the name of the gate that remained underground, and the remaining 11 gates. In the travels of Russian tourists E.K. Meyendorf [4; 183], P.I. Demezon [2; 154], N.V.Khanykov [8; 301] who visited the Bukhara Khanate in the 19th century, MazariSharif of Bukhara, Samarkand, Imam. It is numbered with the names of its gates, such as Uglan, Talipoch, Shergiron, Karakul, Sheikh Jalal, Namazgokh, Sallakhona, Kavol or Karshi [4; 60]. P.I.Demezon expands the information on the city gates and adds their addresses in his journey [2; 57]. According to him, he took them to Hazrat-Imam-Vobkend, where there was a horse market, which opened on Tuesdays; Shergiron - led to the khan's garden on the Khiva road, Talipoch - led to Charbag; The boy was taken to Charjo; Karakul - led to the Karakol principality; Sheikh Jalal; Namazgokh - The road to Namazgokh led to Kabul; Sallakhona - led to the Karmana; Kavolya (or Karshi) - led to Karshi; Mazar-iSharif led to the cemetery of Bahauddin Naqshband, 12 versts from Bukhara; Samarkand - brought to the city of Samarkand.

The above information of P.I.Demezon is also confirmed by the well-known scientist O.A. Sukhareva. According to the scientist, access to the cities of Karakul, Karshi, and Samarkand is carried out through the gates of the same name. The Mazar-i-Sharif and Namazgokh gates connect the city with the road leading to the grave of Bahovuddin Naqshband [7; 38]. O.A.Sukhareva added that the gates of Uglan, Talipoch, Shergiron, Karakul, Sheikh Jalal, Sallakhona, and other large and small villages of the city connected with.

The stories about the travels of Russian tourists who visited the Bukhara Emirate in the 19th century mention the names of not only the capital of Bukhara but also the gates of other cities of the emirate. In particular, 
Khanykov notes that there are 6 gates in the city of Samarkand: Bukhara Gate, Paykabad, Hazrati Zinda Gate, Kalandarkhana Gate, Sozangiron Gate, Khoja Akhror Gate [2; 58]. This information was confirmed by A.P. Khoroshkhin. Bukhara in the west, Paykabad and Shokhizinda in the north, the gates of Kalandarkhana, Sozangiron, and Khoja Akhror in the east [9; 245]. The author also gives information about the gates of Kattakurgan and Penjshamba. Aydar-Oman gates, Samarkand gates in the south and Bukhara gates in the east $[9 ; 127]$ in the north of Penjshambe, such as Kuchakhor, Sarbozor in the east, Kibladarvoza in the west [9; 128]. So, in our opinion, the city gate in the emirate was a peculiar feature of the dacha. According to him, the gate is the name of the city he leads: Samarkand, Bukhara, Karshi, Karakul gate; shrines and various objects at the gates: Mazar-i-Sharif, Hazrati Shokhi Zinda, Khoja Akhror, Sheikh Jalal, Bazar gate, Sarbozor gate; occupation of the population at the gates: Sallakhona, Sozangiron, Shergiron, Kalandarkhana, the geographical position of the gate: Kibladarvoza; etc., it can be concluded that the gate was the basis for the name.

\section{Geographic names are associated with trade and economic processes}

Markets. The role of markets in the internal and external trade of the Bukhara Khanate was enormous, and information about the markets of the Khanate began to appear in the travel notes of Russian tourists who visited Central Asia, mainly from the end of the 18th century. In particular, who arrived at the same time in Bukhara F.S.Efremov wrote: "... not far from the tower in the center of the city there is a market, it is called Chorsu, there is trade from morning to noon; there are 4 caravanserais in the market, built of stone [that is, brick]. In the afternoon, the trade will be at the khan's Sarai. This market is called Registan " [3:120]. In the diaries of mining engineers T.Burnashev and M.Pospelov, who arrived in Bukhara in 1794, the two largest markets in the city center are mentioned as the largest [1:74]. E.K.Meyendorf, who arrived in the Emirate of Bukhara in the 1930s, noted that "in the center of Bukhara you can see streets half a mile long, filled with shops on both sides [4: 77]. According to him, Registan is not a market, but a city center. as a field, and since the market is in the center, we can see that its name was also used concerning the market in earlier periods. E.K. Meyendorf also wrote about the unique markets of Bukhara: "There are crossroads covered with large domes, supported by thick columns," on which "dyed silk, embroidered skullcaps, ribbons, knives, and other things [4:102]. According to O.A.Sukhareva, there are two types of markets in the emirate, the first of which is widespread in Chorsu Samarkand and Shakhrisabz, and the second, Toqi - covered arched markets that exist only in Bukhara. Both are located at the intersection of major streets [7: 43]. Such markets were built since the 16th century, during the reign of Abdullah II, the largest of which are Toqi Zargaron, Toqi Sarrafon, Toqi Telpakfurushon.

P.I.Demezon, who arrived in Bukhara in the 1930s, noted that there were five closed markets in Bukhara, known as Chorsu [2: 58], including Charsui Kalon (big market), Charsui Zargaron (the market for silver and gold jewelry), There were Charsui Sarrafon (money exchange market), Charsui Berinj (rice market) and Tukumduzi (riding horses market for camels) [2: 58]. Timi Adras (mostly local products), Timi Sefid (white market) - Russian and English fabrics are on sale). So, in our opinion, as a result of the development of crafts and trade since the 19th century, 
markets have also expanded, which made it impossible to cover the entire market. It is preserved, taking into account the deterioration in the quality of the product sold in these markets as a result of various external influences. P.I. Demezon added that there are two more markets in the Registan region, the first of which is Bazari-Kagoz (paper market), Bazari Chirchinfurush (groceries, small metal products, handicrafts) [2: 57].

V.N.Khanykov, who visited Bukhara in 1841, noted that there are 22 markets in Bukhara and its environs [2:93]. the process of specialization in products indicates the development of market relations and competition; the presence of a market in any area of the city every day of the week does not meet the needs of the population in large markets, which are held once a week. Also, the construction of markets by private individuals Said Ota, Khoja Arif Ota, in our opinion, on the one hand, follows from the needs of the population, on the other hand, only when markets for domestic and foreign fabrics are built that the Tim style is maybe elements of a monopoly character in market relations.

\section{Caravanserais}

The construction of caravanserais in the Bukhara Khanate, which played almost the same role as markets in trade and economic relations, and the conditions created in them for traders, was also an important issue at the state level. As we saw above, information about caravanserais appears in travel notes almost simultaneously with the markets. In particular, F.S. Efremov mentions that there were 4 caravanserais in Bukhara [3:120] in the diaries of T. Burnashev and M. Pospelov [1: 73]. However, none of the caravanserais is mentioned in the travel notes of these authors. ... As we saw on the example of markets, as a result of the development of trade and economic relations in the emirate since the 19th century, the number of caravanserais has also increased, and we consider them by name in the table below. 


\begin{tabular}{|c|c|c|}
\hline & Russian tourist & The name of the caravanserais mentioned in their travelogues \\
\hline 1 & $\begin{array}{l}14 \text { caravanserais are } \\
\text { listed by E.K. } \\
\text { Meyendorf. }\end{array}$ & $\begin{array}{l}\text { Abdullajon, Kushbegi, hind, nogai, Khoja Juybor, Tashkent, Karshi, } \\
\text { Miragul, Amir, Kulota, Fishana, Dankulla sher, the smallest } \\
\text { caravanserai }\end{array}$ \\
\hline 2 & $\begin{array}{l}25 \text { caravanserais were } \\
\text { listed by P.I. Demezon. }\end{array}$ & $\begin{array}{l}\text { 1) Mirzachul Sarai 2) Karshi Sarai 3) Barra's new Sarai 4) Badriddin's } \\
\text { Sarai 5) Amir's new Sarai 6) Amir's old Sarai 7) Poy-Astana, 8) } \\
\text { Nogaie's Sarai 9) Joybar's Sarai 10) Hind's Sarai 11) Kushbegi's Sarai } \\
\text { 12) Abdullajon Sarai 13) Ismail Khoja Sarai (old) 14) Filxona Sarai 15) } \\
\text { Rajabbek Sarai 16) Kulota Sarai, 17) Ayoz Sarai, 18) Ismail Khoja } \\
\text { Sarai (new) 19) Shona Sarai, 20) Domullo Sher Sarai 21) Sarai of } \\
\text { Aklam, 22) Old Sarai of Barra 23) Sarai of Urgench }\end{array}$ \\
\hline 3 & $\begin{array}{l}\text { I.V. Vitkevich listed } 25 \\
\text { caravanserais. }\end{array}$ & $\begin{array}{l}\text { 1) Sarai Rajabbek devonbegi, 2) Sarai Ayoz, 3) Sarai Nogai, 4) Sarai } \\
\text { Tambaku 5), 6) Khoja, 7) Sarai Pakhta, 8) Sarai Badriddin, 9) Sarai } \\
\text { Mirzachul, 10) Sarai Kushbegi, 11) Sarai Filxona, 12) Sarai Amir, 13) } \\
\text { Amir's new Sarai 14) Sarai Abdullajon, 15) Sarai Karshi, 16) Sarai } \\
\text { Barra, 17) Domulla Sher, 18) Sarai Nogai, 19) Sarai Alam, 20) Sarai } \\
\text { Poyastan 21) Ismailhoja old Sarai, 22) Ismailkhoja new Sarai 23) 24) } \\
\text { 25) Sarai Urgench }\end{array}$ \\
\hline \multirow[t]{2}{*}{4} & \multirow[t]{2}{*}{$\begin{array}{l}\text { In the travelogue of N.V. } \\
\text { Khanykov there are } 38 \\
\text { caravanserais, } 24 \text { of } \\
\text { which are built of stone } \\
\text { and } 14 \text { of brick. }\end{array}$} & $\begin{array}{l}\text { Caravanserais built of stone: 1,2. Urgench Sarai. 3.Abdullah } \\
\text { 4.Qushbegi. 5.Hazati Amir 6.Hakimjon } \\
\text { 7.Ayoz Sarai. 8.Tambaku. 9.10.11. The Sarais of Khoja Juybor. } \\
\text { 12.Nogai 13.Pirxona 14. Kulota 15. Rajabbek devonbegi 16. Payaston } \\
\text { 17.Kozikalon 18.Badriddin 19.Amir Said 20.Barra 21,22, } \\
\text { 23. Tea House 24.Ismailkhoja Sarai }\end{array}$ \\
\hline & & $\begin{array}{l}\text { Wooden Caravanserais: } 1 \text {. Urgench Sarai 2. Brass - Rice Sarai. 3. The } \\
\text { ruined Sarai. 4.Saroyi chit; 5.Jomai zarlatta 6,7,8. Tobacco Sarai } \\
\text { 9,10,11.Mayizsaroy 12.Olacha Sarai 13.Kovushsaroy, 14. Jugutsaroy. }\end{array}$ \\
\hline
\end{tabular}

We see that the number of caravanserais in the emirate has increased significantly over a short period, which indicates the development of trade and economic relations in the emirate. Caravanserais were also widely used, the construction of which was 
accelerated and supported by the state. The reason is that some of the caravanserais built in the 1820 s were soon rebuilt in new conditions. The names of the caravanserais, the names of the merchants who arrived in it: Sarai Tashkent, Sarai Karshi, Sarai Urgench; by the names of the people who built it: Abdullajon, Kushbegi, Badriddin's Sarai, Amir's Sarai, Ismail Khoja's Sarai, Rajabbek's Sarai, Rajabbek's Sarai; name of product stored or sold in caravanserais: Catton Sarai, Tea Sarai, Berinj(rice) sarai, Jomai zarlatta, Tamaki Sarai; because of the nature of the caravanserai: Small caravanserai, the new Sarai of the Amir, the old Sarai of the Amir, the Ayoz Sarai, the new Sarai of Ismailhoja, the new Sarai of Barra; by the names of the peoples living in the caravanserai or its environs: Hindu Sarai, Nogai Sarai, Dzhugutsaroi, etc.

\section{Geographic names are associated with religious and ideological life. \\ Mosques}

The Bukhara Emirate is a special regulator of religious and Sharia affairs among the khanates of Central Asia, and the fact that the rulers of the emirate ruled the country under such honorable names as "Amir ul-Muminin" and "Amir ul-Muslim" shows that religion has a special place in the country. The main religious institutions of the emirate are mosques, the structure, name, and some which are also mentioned in the travel notes of Russian tourists. In particular, in the diaries of the Russian tourist F.S. Efremov, who made a 9-year trip to Central Asia in 1774-1782, “... most of the mosques in the emirate are small. Some of them are stone (brick), one on each street "[3; 120], but does not give the exact number. The diaries of T. Burnashev and $M$. Pospelov, who arrived in Bukhara at the end of this century, say that there were 360 of them, 20 of which were the largest and were in better conditions than the rest $[1 ; 71]$. This information was provided by T.Burnashev and M.Pospelov, who visited the emirate in 1820 . This was confirmed by E.K. Meyendorf, who listed the mosque in front of the mosque and the Registan square as the largest mosque [4; 99].

P.I.Demezon, who visited the emirate in the 30 s of the last century, according to F.S. Efremov about a mosque in each district of the emirate, has 366 districts and mosques [2:57]. It is also considered to be a large mosque. It lists mosques such as Masjidi Kalon, Gaukushon, Misgaron, Masjidi Mogoki. According to I.V. Vitkevich, who came to Bukhara together with P.I. Demezon, there are less than 300 mosques in Bukhara. The largest of them are Masjid Juma, Masjid Gaukushan, Masjid Atalik, Masjid Sari-Khovuz [2:103].

According to V.N.Khanykov, who arrived in Bukhara as part of the Orenburg mission in 1841 , the main religious institution in the country was a mosque, numbering 360 mosques in the emirate, 8 of which are mainly Namazi Juma: 1)Masjidi Baland, 2)Masjidi Usta Rahim, 3)Masjidi Mirakan, 4)Masjidi Juybor, 5)Masjidi Gaukushon, 6)Masjidi Shahana, 7)Masjidi Khalifa Hussein, 8)Masjidi Payond Atalik mosques are more than others [8:84].

Madrassahs. Madrassahs are the main religious and secular educational institutions in the emirate and are the most under construction architectural sites in the emirate after mosques. More information about the madrassah of the Emirate began to appear in the travel notes of Russian tourists almost simultaneously with the mosques, that is, from the second half of the 18th century. In particular, F.S. Efremov wrote in his memoirs that "... in the city there are 8 two-story stone 
(brick) buildings [3:120], they are called madrassahs" [3:120]. But in the travel stories of this period. the names of madrassahs are hardly mentioned. More extensive information about the Bukhara madrassah has been found since the 19th century, and in the diaries of E.K. Meyendorf's largest madrassahs are Subkhankulikhan, Kokaldosh, Ernazar Elchi madrassah, Madrassah Mir Arab, Abdulmomin, Madrassah Chorbakr [4:100] I.V. Witkiewicz, who arrived in the emirate shortly after E.K. Meyendorf, noted that there are 70 madrassahs in the emirate, the most famous of which is Mir Arab [2:103]. According to the author, there are 103 madrassahs in the emirate, the largest of which are the Kokaldosh madrassah, the Miri Arab madrassah, the Mirzo Ulugbek madrassah, the Zargaron madrassah, the Tursunjon madrassah, the Muhammad Sharif merchant madrassah, the Abdullakhan madrassah, others [2:86]. In addition to the indicated 8 madrassahs, the play also lists 52 madrassahs, 60 madrassahs in total, as well as some additional information about them [2:57].

Mausoleums and cemeteries. Information about mausoleums and cemeteries in the emirate is found in Russian travel notes only from the 19th century, and E.K Meyendorf gives information about the Bukhara madrassah, the Chorbakr madrassah - a unique architectural complex that includes mausoleums and tombs [2:57]. In the memoirs of P.I. Demezon, as we saw above, one of the gates is called Mazar-i-Sharif, which indicates that there is a tomb of the same name next to them. The author also adds that through these gates he got to the mausoleum of Bakhovuddin Nakshband, 12 versts from Bukhara [2:62].

Information about the cemeteries of the emirate can be found in the travel note of $\mathrm{V}$.
N. Khanykov, who mentions the names of 13 cemeteries. These are
1. Imam Kazikhan,
2. Khoja Taband,
3. Khoja Nurabad,
4. Khoja Bulgar,
5. Khoja Turki Jandi
6. Mirakan,
7. Ishan Khoja Khudaidod,
8. Goristan Juybor,
9. Khazrati Eshan,
10. Khazrati Eshan Habibulla,
11. Khazrati Rushnoi,
12. Khojasp gardan,
13. Kimsangiron cemeteries.

The peculiarity of the name of the mausoleums and cemeteries is that most of them are anthroponyms named after the great saints buried here, eshans, khoja: Bakhovuddin Naqshband, Khoja Nurabad, Khoja Bulgar, Khoja Turki Dzhandi, Eshan Khoja Khudeidod, Imazabi Eshan; cemeteries where only certain people or a certain class of society are buried Guristoni Juybor, Kimsangiron; cemeteries that bear the same name as the mosque because they are part of the mosque: Mirakan; toponyms associated with the neighborhood or the territory where the cemetery is located: we see that it was formed based on Khojaasp gardan [8:83].

\section{Names associated with the cultural and consumer service system. Pools}

Relatively more detailed information about the basins in the emirate is based on V.N. In Khanykov's memoirs, the author writes that there were 83 swimming pools in Bukhara. These pools are named after the people who built them: Devonbegi, Mulla Ashur, Khoja Bulgor, Atalik Mirza Gafur, Kazikalon, Istemurbiy; Names of nearby public facilities: Khoja Ismail Somoni, Mirdostim, Kunjak 
Hammam, Khoja Zainiddin, Gavkushan, Karhon Labi basin, Mir Akon, Gavkushan; by the name of certain categories of society: Dzhugutlar basin, Kimsangiron, Khojatobon basin, Mullalar basin, Juybor basin; we can also see that it is also named after the name of the area in which it is located: Callabod, Gazian.

\section{Bathrooms}

The first information about existing baths in Central Asia was found in the diaries of Russian tourists by FS Efremov, who said that "... there are no baths in Bukhara, except for private baths belonging to the emir" [3:120]. However, according to O.A. Sukharev, information about the existence of baths in Bukhara first appeared in the works of Narshakhi in the 10th century [7:62]. He added that in the 15th century during the reign of Mirzo Ulugbek and in the 16th century during the reign of Abdullah II, many public baths were built in the city. [7:63] T. Burnashev and $M$. Pospelov add that in the cities of the khanate there were many baths, mainly stone (brick), and baths for men and women were separate [1:71].

According to E.K. Meyendorf, a Russian tourist who visited Bukhara in the 19th century, there were 14 public baths in Bukhara [4:102] P.I. Demezon, who visited Bukhara a little later, noted that there are 50 baths in the city, the largest of which, Tukimduzi and Misgaron, add that there are baths [2:64]. We see that the sharp increase in the number of public baths in a short period is a sign that the public service system in the city has improved. Information about the baths of Bukhara was confirmed by V.N. Khanykov, who called it one of the largest baths in the city

1. Hammomi Bazaar Khodja,

2. H. Nau,

3. H. Misgaron,
4. H. Abdulla Khoja,

5. H. Glass,

6. H. Juybor,

7. H. Cloth,

8. H. Gaukushon,

9. H. Dobbian,

10. H.Bazari Nau,

11. H. Sarrafon,

12. H. Chashmai Ayub,

13. H. Obiotash,

14. H. Poyastan,

15. H. Zargaron,

16. H. Kunjak.

The formation of the name of the baths is the same as that of other public institutions in the emirate, mainly by the name of the area in which they are located, and not only: baths of Misgaron, Shishakhona, Tukimdozi, Gaukushon, Sarrafon, Zargaron; The name of the person who built the object: Hammami Bazaar of Khoja Abdullah Khoja; belonging to certain social strata: Hammami Juybor; if it is built inside or next to an architectural complex: we see that it is called by such names as Hammami Chashmai Ayub, Hammami Poyastan.

\section{CONCLUSION}

As we can see, studying urban microtoponymy in travel on the example of the Bukhara Emirate, one can study many interesting aspects of the trade and economic situation of cities, social topography, and preparation of the population. The reason is that microtoponyms were used by ordinary people for a short historical period, and their frequent transformation is directly related to various political, historical, and ethnocultural processes in the region. 


\section{REFERENCES}

1. Burnashev T. Travel from the Siberian line to the city of Bukhara in 1794 and back in 1796 // Siberian Bulletin (published by Gr. Spassky) -Spb., 1818. -P. 110.

2. Notes on the Bukhara Khanate (Reports of P. I. Demezon and I. V. Vitkevich). - M .: Nauka, 1983 .- p. 154.

3. Lunin B.V. History of Uzbekistan in sources. News of travelers, geographers and scientists of the XVI-first half of the XIX century. - T .: Fan, 1988 .- P. 257.

4. Meyendorf E.K. Travel from Orenburg to Bukhara. - Moscow: Nauka, 1975. -p. 183.

5. Envoy of Peter $I$ in the East. Florio Beneveni's embassy to Persia and Bukhara in 1718-1725. -Moscow, 1986. -p. 162.

6. Philip Efremov's wanderings in the Kirghiz steppe, Bukharia, Khiva, Persia, Tibet and India and his return from there through England to Russia. Third edition. Kazan, 1811. -p.160.

7. Sukhareva O. A. Bukhara XIX - early XX century (Late feudal city and its population). -M .: Nauka, 1966. -p. 330.

8. Khanikov N.V. Description of the Bukhara Khanate. - SPb., 1843 -- p. 301.

9. Khoroshkhin A.P. Collection of articles related to the Turkestan region. -Spb., 1876. -p. 533.

10. Doniyorov A., \& Karimov N. R. (2020). The historical significance of" dastur ulmuluk"("guide to the kings") by khoja samandar termizi. Journal of Critical Reviews, 7(6), 159-162.

11. Doniyorov, A. Kh. and Karimov, N. R. (2019) "-KITAB AL-HIKMAHII AND -HIKMAHII IN HAKIM TIRMIDHI'S SCIENTIFIC HERITAGE," Central Asian Problems of Modern Science and Education: Vol. 4 : Iss. 2 , Article 191. 